Kajian Jurnalisme

Volume 04 Nomor 01 Tahun 2020

DOI: $10.24198 / j k j . v 4 i 1.24071$

\title{
Media Agenda on Yogyakarta Sultanate Succession
}

\author{
Kharisma Nasionalita, Catur Nugroho \\ Faculty of Communication \& Business, Telkom University, Bandung. \\ nasionalita.kharisma@gmail.com
}

\begin{abstract}
Yogyakarta is a province with special status in Indonesia, bound by unique local political rules. According to The Mandate of Law Number 13 of 2012 concerning the Privileges of Yogyakarta, the position of Governor and Deputy Governor must be filled by the determined leaders of the palace. Yogyakarta's local politics went under the spotlight when Sultan Hamengku Buwono crowned his eldest daughter to be the successor to the palace's leadership in his Sabdatama (Kings Order). National regulation does not mention the gender of the Governor and Deputy Governor while in the internal court of the Yogyakarta palace, the position of a leader must be occupied by men. The issue gained intensive national media attention throughout March-May 2015, particularly by Kompas, Republika, and Kedaulatan Rakyat. This research aims to measure the media agenda related to the issue of the Sultanate succession on three selected newspapers. Through the quantitative content analysis method, this research dissects how the media places and emphasizes this issue. The purpose of this research is to identify how issues are prioritized through news content. There are 62 news articles selected from the period March-May 2015. The result of the research shows that all media emphasizes the Sultanate issue in different ways. There is a distinction between the local newspaper Kedaulatan Rakyat and the national newspaper (KOMPAS and Republika). The local newspaper put monarchy issue in the second rank while the national newspaper set constitutional issues such as the polemic prerequisite of Yogyakarta Governor and Deputy Governor in second place.
\end{abstract}

Keywords: media agenda; content analysis; newspapers; sultanate succession; yogyakarta

\begin{abstract}
Abstrak
Yogyakarta adalah provinsi dengan status khusus di Indonesia, terikat oleh aturan politik lokal yang unik. Menurut Mandat Undang-Undang Nomor 13 Tahun 2012 tentang Hak Istimewa Yogyakarta, posisi Gubernur dan Wakil Gubernur harus diisi oleh para pemimpin istana yang ditentukan. Politik lokal Yogyakarta menjadi sorotan ketika Sultan Hamengku Buwono memahkotai putri sulungnya menjadi penerus kepemimpinan istana dalam Sabdatama-nya (Perintah Raja). Peraturan nasional tidak menyebutkan jenis kelamin Gubernur dan Wakil Gubernur sementara di pengadilan internal istana Yogyakarta, posisi seorang pemimpin harus ditempati oleh laki-laki. Masalah ini mendapat perhatian media nasional yang intensif sepanjang Maret-Mei 2015, terutama oleh Kompas, Republika, dan Kedaulatan Rakyat. Penelitian ini bertujuan mengukur agenda media terkait isu suksesi Kesultanan di tiga surat kabar terpilih. Melalui metode analisis konten kuantitatif, penelitian ini membedah bagaimana media menempatkan dan menekankan masalah ini. Tujuan dari penelitian ini adalah untuk mengidentifikasi bagaimana masalah diprioritaskan melalui konten berita. Ada 62 artikel berita yang dipilih dari periode Maret-Mei 2015. Hasil penelitian menunjukkan bahwa semua media menekankan masalah Kesultanan dengan cara yang berbeda. Ada perbedaan antara surat kabar lokal Kedaulatan Rakyat dan surat kabar nasional (KOMPAS dan Republika). Surat kabar lokal menempatkan masalah monarki di peringkat kedua sementara surat kabar nasional mengatur masalah konstitusional seperti prasyarat polemik Gubernur Yogyakarta dan Wakil Gubernur di tempat kedua.
\end{abstract}

Kata kunci: agenda media; analisis konten; koran; suksesi kesultanan; yogyakarta

Korespondensi: Kharisma Nasionalita, S.Sos., MA, Telkom University, Jl. Telekomunikasi No.1, Terusan Buahbatu, Bandung. 085711008386, Email: nasionalita.kharisma@gmail.com

Menyerahkan: Oktober 2019, Diterima: Juni 2020, Terbit: Juli 2020

ISSN: 2549-0559 (cetak), ISSN: 2549-1946 (online), Website: http://jurnal.unpad.ac.id/kajian-jurnalisme 


\section{INTRODUCTION}

Yogyakarta, as one of the privileged areas in Indonesia with a system of local governance that does not apply the elections to determine the regional head, is a rare and special step in the country. Referring to the Law No. 13 of the year 2012 about the privileges of Yogyakarta, the position of Governor of the special region of Yogyakarta filled by the heir to the throne of Kasultanan Yogyakarta, while for the position of Deputy Governor is filled by the heir to the throne of Kadipaten Paku Alam. The embedding of this mental status can be interpreted as a recognition of the central government to the existence of the Royal System (monarchy) in Yogyakarta province beside a parliamentary democracy system that remains. The existence of Mandate of Law No. 13 of 2012, on one side, is seen as a central government effort to regulate the government system in Yogyakarta, but on the other hand, also becomes a tool that is to be a means of giving to Kasultanan and Puro Pakualaman in Yogyakarta. The determination of the Governor and the Deputy Governor has raised problems relating to the Sultan's cultural power as the holder of the power of Yogyakarta Sultanate and the political power of the Sultan as the Governor of the special region of Yogyakarta. The implication of the Yogyakarta Privileges Law is a system of monarchy that runs together with a democratic system. The power in Yogyakarta is not in total control of the Sultan's hand, but there is still a system of supervision from the provincial DPRD in implementing regional government. If the concept of the trias politica adopted by the unitary state of the Republic of Indonesia is drawn into the system and also applied in Yogyakarta, then the holders of power at the executive level are held by the Governor of the Special Region of Yogyakarta, in this case, the Sultan Hamengku Buwono X, while the legislative power is held by the Yogyakarta Provincial DPRD which is a representation of the people of Yogyakarta.

This phenomenon of power succession in Yogyakarta attracted various groups, including the public and the media, especially when the emergence of dissent was related to the interpretation of the Special Law of Yogyakarta article 18 paragraph (1) letter m which implicitly required candidates for governor and vice-governor of the Special Region of Yogyakarta must be male. This triggered problems in the internal environment of the Yogyakarta palace because Sultan HB X did not have sons as the throne of the king, as well as the successor to the power of government in Yogyakarta Province. The debate over the terms of the Yogyakarta governor candidate emerged when DPRD discussed the Draft Regional Regulation (Perdais) about the Procedure for Filling the Position, Inauguration, Position, Duty, and Authority of the Governor and Deputy Governor. Article 3 Paragraph (1) letter $m$ of the rule states, Governor and Deputy Governor candidates must submit a curriculum vitae, including a history of education, employment, siblings, wife, and child. The sound of the article is exactly the same as Article 18 Paragraph 1 letter m of Law Number 13 of 2012 concerning Yogyakarta Privileges. Some people interpreted it, the article requires the governor and Yogyakarta deputy governor must be male.

Discussions about the Sultanate succession received media attention when Sultan Hamengku Buwono X issued Sabdatama (King's Order). The first Sabdatama on Friday, March 6, 2015, Sultan Hamengku Buwono was stated that anyone is forbidden to discuss the succession of the Kraton Yogyakarta, both from the internal palace and from the elements of government, because the highest authority entitled to discuss the issue in the Kingdom of Mataram is only the King or Sultan. Sabdatama on the one hand is a representation of the Sultan's power as King, but on the other hand, simultaneously closes the space for democracy to develop in Yogyakarta. Next, the debate arose concerning women's opportunities to become the Governor of Yogyakarta. The opinion that developed in the media in response to Sabdatama (King's 
Order) was divided into two camps. Sultan Hamengku Buwono X considers that women have the same rights as men to be rulers in the Mataram kingdom. Meanwhile, the Sultan's brothers and several courtiers considered that according to the Kraton Yogyakarta customs that had been valid since the time of Sultan Agung, the king of Mataram had to be a man, because besides being a king, the Sultan in Yogyakarta was also the leader of the Islamic religion. This debate intensified when Sultan Hamengku Buwono X issued the second Sabdatama on 30 April 2015 which changed the title of "Sultan Hamengku Buwono" to Sultan "Hamengku Bawono". The second was issued on May 5, 2015, the contents of which replaced the Sultan's first daughter GKR Mangkubumi as a Crown Princess who would replace the Sultan Hamengku Buwono X as the King of the Sultanate of Yogyakarta who is also the Governor of the Special Region of Yogyakarta. Some of the courtiers of the Yogyakarta Palace, especially the Sultan's siblings, rejected the decision because it was considered not in accordance with the customs prevailing in the Sultanate of Yogyakarta so far.

The emergence of this polemic and conflict triggered mass media in Indonesia, both print and electronic, to bring it to the news. The coverage of the issue in the end both directly and indirectly floated the discourse about leadership succession in Yogyakarta. Some active media published news about the issue of Sultanate Succession in Yogyakarta intensely during the period from March to May 2015.

Table 1. Intensity of Media Coverage Issues on Yogyakarta Sultanate Succession

\begin{tabular}{|c|c|}
\hline Daily Newspaper & $\begin{array}{c}\text { News Intensity } \\
\text { (March - May 2015) }\end{array}$ \\
\hline KOMPAS & 20 news \\
\hline Kedaulatan Rakyat & 28 news \\
\hline Republika & 14 news \\
\hline Tempo & 24 news \\
\hline Suara Merdeka & 6 news \\
\hline Jawa Pos & 9 news \\
\hline
\end{tabular}

Source: Pre-research 2019

The phenomenon of power in Yogyakarta is interesting to be studied further, especially when the problem arises in the internal affairs of Yogyakarta Palace when Sultan Hamengku Buwono X does not have a son as heir to the king's throne, as well as a successor to the rule of government in Yogyakarta province. The pros and cons arise because the Sultan is considered preparing his eldest daughter to become heir to the throne. During this time the Kingdom of Yogyakarta firmly holds the tradition that the king must be a descendant of a royal bloody male. The internal affairs of Yogyakarta Palace then sparked local political upkeep considering that the governor's position will be filled by the successor of the Yogyakarta kingdom. While in Indonesian regulation, the central government grants equal rights between men and women to be government leaders both at the central and regional levels. The issue of succession that originated from the internal affairs of Yogyakarta Palace then attracted local and national media attention, especially how democracy grows in Yogyakarta where a system of monarchy runs together with a democratic system.

However, media can direct issues to the public. Sindo Newspaper as an example has blocked stories about US President Donald Trump ban on the arrival of people from seven Middle Eastern and African countries to enter the US, due to the closeness of Sindo Newspaper owner Hary Tanoesoedibjo with Donald Trump. No news that criticizes Trump's policies 
printed in Hary Tanoesudibjo's newspaper (Lesmana, 2017). Another example, Kompas posed a bivalent role simultaneously: agent of restraint and agent of stability in the news of President Abdurrahman Wahid impeachment in 2001 (Priyonggo, 2012). Therefore, the media can create an agenda where the issues are mixed to be discussed by the public.

Media gives attention differently to each issue or event, consequence, it will affect the public's cognition (concerning knowledge and image) on an event in the public's eye. Media has an essential role in the framework of the concept of good governance because, in essence, the principle of good governance requires participation and transparency, which is a significant key in the involvement of stakeholders, especially related to governance matters, which concerns public policy (Nugroho, 2014). Then, Media Agenda related to Yogyakarta Sultanate Leadership Succession shaped and public opinion colored by several sub-issues. This research is going to describe the media agenda related to the Sultanate Succession issue in Yogyakarta at KOMPAS, Republika, and Kedaulatan Rakyat.

This research is measuring the media agenda on three selected daily newspapers with high intensity through purposive sampling: KOMPAS, Kedaulatan Rakyat, and Republika. There was a total of 62 news items are measured. This research will be conducted with a focus on reporting on the issue of leadership in Yogyakarta in three national and local newspapers, namely KOMPAS, Republika, and Kedaulatan Rakyat.

The three media were selected based on historical considerations, ideology, and distribution (circulation) of the media up to the issue of leadership succession in Yogyakarta which became the media's attention in 2015. Besides, it was also based on the intensity of the issue of leadership succession in Yogyakarta that emerged from the three media in the period March to May 2015. Another factor that was taken into consideration in the selection of the three media was how the three media presented actors involved in the conflict that occurred in Yogyakarta in the context of Javanese rule and Islam. As a national mass media, KOMPAS, which first appeared on June 28, 1965, cannot be separated from its history as a newspaper affiliated to the Catholic Party. The birth of KOMPAS which brought the vision of "transcendental humanism" and later changed to "Mandate of the People's Conscience" began with the proposal that Catholics have daily newspapers to balance the PKI media at that time. The history of the birth of KOMPAS and the style of reporting that was shown was inseparable from the proximity of KOMPAS to the nationalist party. Hamad said that as a media affiliated with the Catholic Party at the beginning of the old order period, KOMPAS was then close to nationalist and Christian parties at the beginning of the new order period, such as the Indonesian Democratic Party (Hamad, 2004)

Republika is a daily newspaper born on January 4, 1993, and driven by the Indonesian Muslim Scholars Association (ICMI). The mission of Republika is in line with ICMI's mission to carry out the mission of Islamic ideology. Meanwhile, Republika's vision is to become an integrated national print media company and managed professionally in Islam, so that it influences the process of educating the nation, developing culture, and increasing faith and piety in the lives of new Indonesian people. While the third media that became the object of this research was Kedaulatan Rakyat as local media published for the first time on Thursday, September 27, 1945, or 40 days after the Proclamation of Indonesian independence was declared. The birth of Kedaulatan Rakyat or KR was spearheaded by Samawi, Soemantoro, and Bramono, who initially opened the seal of the Japanese propaganda office, Sinar Matahari, to publish a replacement newspaper that fueled the struggle.

Over time, the daily newspaper Kedaulatan Rakyat until 2010 was the largest daily newspaper in Yogyakarta and part of Central Java and ranked 6th in the largest daily newspaper 
of national readers. With an average circulation of more than 120,000 copies and the average number of readers every day more than 500,000 people, Kedaulatan Rakyat is the most widely read daily newspaper by the people of Yogyakarta and parts of Central Java. As the oldest and largest local daily newspaper in Yogyakarta, Kedaulatan Rakyat has an interest in the dynamics of local politics in the Yogyakarta region as its customer based.

First, this research-based on the Agenda Setting theory. The Agenda Setting starts with two thought initiated by Walter Lipmann and Bernard Cohen. Walter Lipmann looked mass media as a painter of reality, audiences cannot and cannot experience all events, even those events require a response from the public. Walter Lipmann sees reality created by the media then the public will respond to the reality created by the media. In Bernard Cohen's view, mass media influence public perception about what people think but the press succeeds in convincing and forming perception public about what people think but the press succeeds in convincing and forming perception audience (Nasionalita, 2014). In this regard, the mass media has the power to determine the portion or priority scale of an issue or event in the presentation so that public perception is formed.

Dearing and Rogers state that the agenda is defined as a "set of issues that are communicated in a hierarchy of importance at a point in time ". An agenda is a group of issues that are communicated in the order of importance over time certain (Nasionalita, 2014). Agenda Setting is defined as a process in competition ongoing issues between issues proponents for attention media, public and policy-making elites. In the process, Agenda Settings can be divided into three sub-areas; agenda media, public agenda, and policy agenda. Public Agenda is a subarea trying to understand how public opinion is influenced by mass media content. While the agenda of the media settings themselves is a study that emphasizes media content related to issue definition, selection, and emphasis done by the media. Policy Agenda or Policy Agenda related to relations between public opinion on elite policies, decisions, and action (Mrogers \& Wdearing, 1988) nothing can fail. Without it, nothing can succeed. Consequently, he who moulds public sentiment goes deeper than he who enacts statutes and pronounces decisions (U.S. President Abraham Lincoln, quoted in Rivers, 1970, p. 53. Empirically, Agenda Settings is tested first in the selection president of the United States in 1968. Research conducted by Maxwell McCombs and Donald L Shaw compared issues actual campaign in the mass media with what the voters say as important issues. The results showed that there was a relationship by mass media with issues that are considered important for voters (McCombs \& Shaw, 2016).

When compared between issues that are considered important by the media and issues considered important to the public, the result was significant. In the study, it was seen that the media mass through Agenda Setting can select and underline certain issues through editorial. The editorial room is a place where issues and events are arranged, then sorted by priority scale before being communicated to the public. Journalists are part of the process in the editorial room. They gathered issues and events, and it is being selected by a gatekeeper in the editorial room, then the news will be delivered to the public. Griffin said that there was a problem: "Most of us can't pay equal attention to more than a dozen issues. Time and mental energy are scarce resource (Griffin, EM, Ledbetter, Andrew, and Sparks, 2019). Amid the demands of school, work, relationships, and the daily cores of life, we have to choose which issues get some of our precious attention spans. The small set of issues that's most important to you at the moment is your agenda. Taking the average of those concerns across an entire community, state, or nation is public agenda - the set of issues most salient (in other words, that capture attention) across a group of people at a given time." 


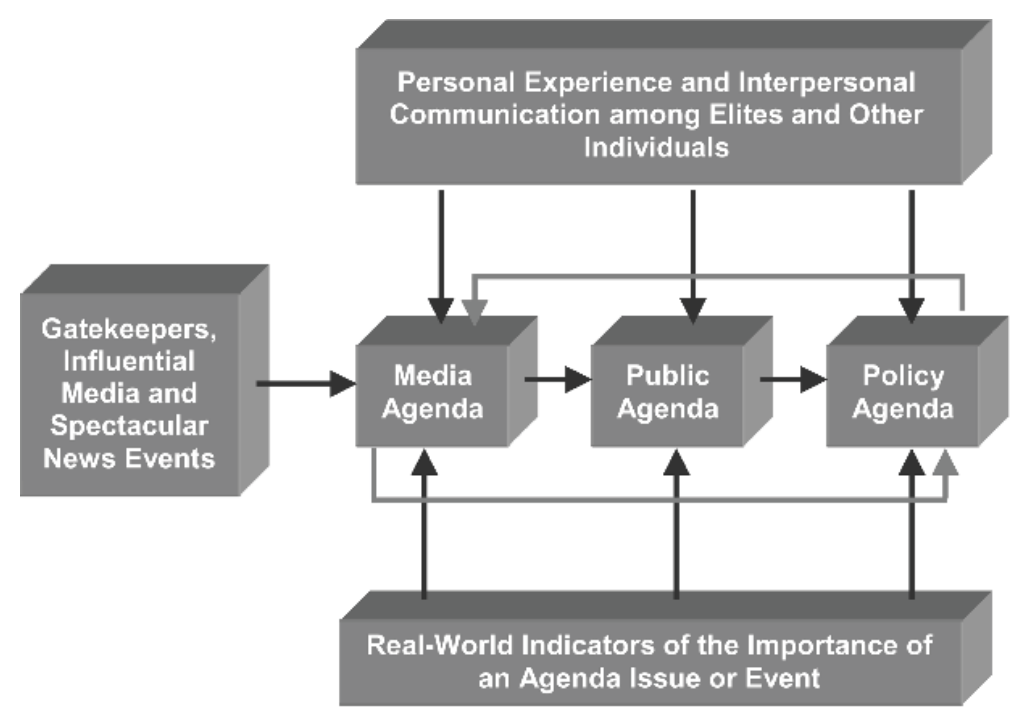

Figure 1. Agenda Setting

Source: (Nasionalita, 2014)

Secondly, for shaping these studies, researchers put Media Agenda on literature. For the next stepping theory of Agenda Setting, there were developing concepts: Media Agenda. According to how media giving attention to special issues, some studies emphasize media content. For mass-media especially gatekeepers put efforts to get attention from the public. They give special treatment for media content in the editorial room. the agenda-setting of the prominence of certain issues by the mass media should not be separated from the media selection process, this selection process has stages or several doors (gates), can individuals or groups decide is newsworthy of loading. These are those who play a role in informing the reality in the public - called the gatekeeper. Usually, the gatekeeper determines the weight of the issue presentation based on how much space provided, the prominence of news (size of headlines and location placement page), and the way the issue is discussed in detail or in general (DeGeorge, 1981). Media Agenda is a determination issue that is considered important to be reported in media. Usually, the media agenda is poured out in the order of priority. Merheim said that The media agenda consists of issues, actors, events, assumptions, and views that take advantage of time and space in the available publications to be submitted is public (Nasionalita, 2014).

\section{METHOD}

This study uses content analysis method with quantitative research. It is summed up as data and then analyzed. While this research is describing a particular message or text. Content analysis is a research technique for making inferences carried out objectively and systematic identification of message characteristics. (Eriyanto, 2011) also explains that content analysis is also used to study the contents of all contexts of communication both interpersonal, group, or organizational communication. As long as there are documents available, the analysis can be applied. In using content analysis, researchers can study the description of the content, characteristics of the message, and developments (trends) of content.

The population of this study is six newspapers (see table 1. The intensity of Media Coverage Issues on Yogyakarta Sultanate Succession in Indonesia). Through pre-research, researchers calculated the frequency of media coverage from national and local newspapers concerned about raising the issue of the succession of the sultanate of Yogyakarta. There are 6 media (both national newspapers and local newspapers) in the population including KOMPAS, Republika, 
Volume 04 Nomor 01 Tahun 2020

DOI: $10.24198 / j k j . v 4 i 1.24071$

Kedaulatan Rakyat, Tempo, Suara Merdeka, Jawa Pos. based on the population of newspapers in Indonesia in pre-research (see table 1), researchers then draw samples purposively based on criteria: they are national newspapers and local newspapers in Indonesia, these media have the highest media coverage reporting on the issue of Sultanate Succession in Indonesia during the period from March to May 2015. Researchers calculated media coverage and obtained 3 media that reported intensively on the issue: KOMPAS, Republika, and Kedaulatan Rakyat. There were 3 sample newspapers selected with the highest news intensity (see table 1) with a total of 62 news items examined during the period from March to May 2015.

Next, the researcher makes operationalization based on the message content indicators related to the issue. Message content in news is then divided into two categories. The first category is the sub-issue, with the class division as follows: Sabdatama (King's order), the polemic prerequisite of the governor and deputy governor of Yogyakarta, Controversy over a female ruler or Sultanah in Yogyakarta, Female governor in Yogyakarta, issue of democracy and Monarchy issue. The second category is the division of actors that emerge and give statements as long as the news related to the issue is contained in the class division: external actors outside the circle of the kingdom of Yogyakarta that mentioned on news. Researchers then measure the media agenda through ranking issues based on news frequency, placing news (headlines or not), types of news reviewed on soft news or hard news, and news length. The researchers collected news from the three selected media and found thematic sub-issues that were found in the field. The news is then grouped into sub-issues specific sub-issues: Sabdatama (King's Order), The Polemic Prerequisite of Governor and Deputy Governor, Controversy over female Ruler or Sultanah, Female governor in Yogyakarta, Issue of Democracy, and Monarchy issue.

\section{FINDINGS AND DISCUSSION}

Lang, Gladys E \& Lang, (1981) mention the issue in five interpretations; (1) the issue can be a concern or a problem of concern public person. (2) In the form of perception of key problems, or perceptions and elaboration of problems faced by the community. (3) In the form of dissemination of possibilities that must be chosen by the public, agree or do not agree to a policy. (4) In the form of public controversy, a problem that contains pros and cons in society. (5) In the form of reasons or factors that determine the way out in a political gap. Shaw distinguishes between events and issues. The first result, news scoring, and Issues rank result over three Newspapers; Kompas, Kedaulatan Rakyat, and Republika.

According to table 2, Researchers measured the media agenda through ranking issues based on news frequency, placing news (headlines or not), types of news reviewed on soft news or hard news, and news length.

Table 2. News Scoring at Kompas, Republika and Kedaulatan Rakyat

\begin{tabular}{|l|c|c|c|}
\hline \multicolumn{1}{|c|}{ Issue } & Kompas & Republika & $\begin{array}{c}\text { Kedaulatan } \\
\text { Rakyat }\end{array}$ \\
\hline Sabdatama (King's Order) & 83 & 60 & 148 \\
\hline $\begin{array}{l}\text { The polemic Prerequisite of Governor and Deputy } \\
\text { Governor }\end{array}$ & 72 & 24 & 27 \\
\hline Controversy over female ruler or Sultanah & 30 & 6 & 32 \\
\hline Female governor in Yogyakarta & 54 & 0 & 28 \\
\hline Issue of Democracy & 12 & 6 & 0 \\
\hline Monarchy issue & 72 & 6 & 75 \\
\hline
\end{tabular}

Source : Research result (2019) 
Volume 04 Nomor 01 Tahun 2020

DOI: $10.24198 / \mathrm{jkj} . \mathrm{v} 4 \mathrm{i} 1.24071$

Table 3. Issue Rank at KOMPAS, Republika and Kedaulatan Rakyat

\begin{tabular}{|l|c|c|c|}
\hline \multicolumn{1}{|c|}{ Issue } & Kompas & Republika & $\begin{array}{c}\text { Kedaulatan } \\
\text { Rakyat }\end{array}$ \\
\hline Sabdatama (King's order) & 1 & 1 & 1 \\
\hline $\begin{array}{l}\text { The polemic Prerequisite of Governor and Depu- } \\
\text { ty Governor }\end{array}$ & 2 & 2 & 5 \\
\hline Controversy over female ruler or Sultanah & 4 & 3 & 3 \\
\hline Female governor in Yogyakarta & 3 & - & 4 \\
\hline Issue of Democracy & 5 & 3 & - \\
\hline Monarchy issue & 2 & 3 & 2 \\
\hline
\end{tabular}

Source: Research result (2019)

After scoring, the result indicated that the media gave special attention to sub-issues Sabdatama (King's Order) since Sri Sultan Hamengku Buwono X sentenced it twice to the public. First on Friday, March 6, 2015. Sabdatama, it was stated that anyone is forbidden to discuss the succession of the Kraton Yogyakarta, both from the internal palace and from the elements of government, because the highest authority entitled to discuss the issue in the Kingdom of Mataram is only the King then Sultan immediately changed the title of Sultan Hamengku Buwono to Sultan Hamengku Bawono on 30 April 2015. The second was issued by Sultan on May 5, 2015, the contents of which replaced the Sultan's first daughter GKR Mangkubumi as Crown Princess who would replace the Sultan HB X as the King of the Sultanate of Yogyakarta who is also the Governor of the Special Region of Yogyakarta. The media stressed Sabdatama issue out to bold Sultan's presence as a cultural and political ruler. If we analyze partially, local newspapers give more attention to the same issue than the other two national newspapers. News scoring shows that Kedaulatan Rakyat is superior at 148, while the Kompas is 83 and Republika is 60.

The issue of leadership succession in Yogyakarta is a local issue that attracts both local and national media, however, local newspapers give more attention because of the closeness of the issue with their readers. National media concerning this issue because of Yogyakarta Province was a special case of asymmetric decentralization in Indonesia. The mandate of Law Number 13 of 2012 shows concerning the Privileges of Yogyakarta Province. The Mandate of Law underlines power share both political and cultural. This has become one of the features of Yogyakarta compared to other regions in Indonesia, which can be interpreted as the recognition of the central government on the existence of a royal system (monarchy) in the Yogyakarta Province where the Sultan and Paku Alam were an integral part of the administration of the Special Region of Yogyakarta.

From March-May 2015, both local and national media put the highest attention in May 2015 especially for Sabdatama issue according to table 4. In May 2015 Sultan sentenced Second Sabdatama where it stated his first daughter GKR Mangkubumi as a Crown Princess. In Yogyakarta's patriarchal society, King or Sultan must be male. After several centuries Sabdatama stated Crown Princess who will be the first female ruler of Yogyakarta. The issue of women's leadership is a matter of debate in Indonesia which mostly embraces patriarchal culture both in cultural and political contexts. While Javanese culture discusses women's leadership, the appointment of GKR Mangkubumi as the Crown Princess is something unusual. The predecessors of the sultans were always male.

The second rank issue is the polemic Prerequisite of Governor and Deputy Governor of Yogyakarta. The issue of female leaders in the context of national and local politics is interesting to discuss. The succession of power in Yogyakarta attracted the attention of various 
Volume 04 Nomor 01 Tahun 2020

DOI: $10.24198 /$ jkj.v4i1.24071

groups, including the media, especially when the emergence of differences of opinion related to the interpretation of the Yogyakarta Privileges Law article 18 paragraph (1) letter m which implicitly requires that the prospective governor and prospective vice governor of the Special Region of Yogyakarta be male. The debate over the requirements for DIY governor candidates arose when the DPRD DIY discussed the Draft Regulation of the Special Region (Perdais) DIY regarding the Procedures for Filling in the Position, Inauguration, Position, Duties, and Authorities of the Governor and Deputy Governor. Article 3 Paragraph (1) letter (m) of the regulation states that candidates for governor and candidates for the Deputy Governor of Yogyakarta must submit a curriculum vitae, including educational history, work, siblings, wife, and children. The sound of the article is the same as Article 18 Paragraph 1 letter (m) of Act Number 13 of 2012 concerning DIY Privileges. Some people interpret that the article requires the governor and the Deputy Governor of Yogyakarta to be held by men. This is a concern of the media because in local politics there are laws that are gender-biased even though the political rights of women or men are guaranteed by the Indonesia constitution. Both of national newspaper Kompas and Republika put this constitutional aspect (The polemic Prerequisite of Governor and Deputy Governor issue) on the second rank, but local newspaper Kedaulatan Rakyat was not. Kedaulatan Rakyat prefers to build their agenda on the Monarchy issue as the second rank. Based on news scoring, Kompas treated both The Polemic Prerequisite Governor $\&$ Deputy Governor in the second rank. (see table 2 and 3).

Table 4. Sabdatama (King's Order) Issue from March-May 2015

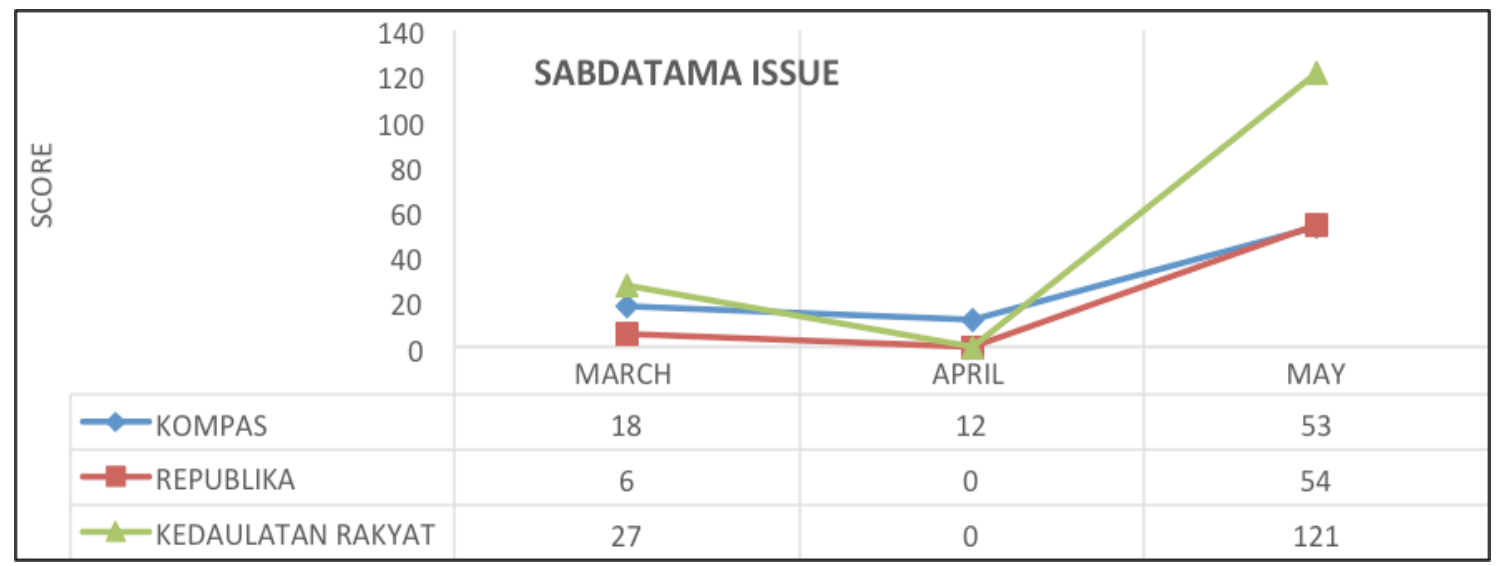

Source: Research result 2019

Tabel 5. The Polemic Prerequisite of Governor and Deputy Governor Issue from March-May 2015

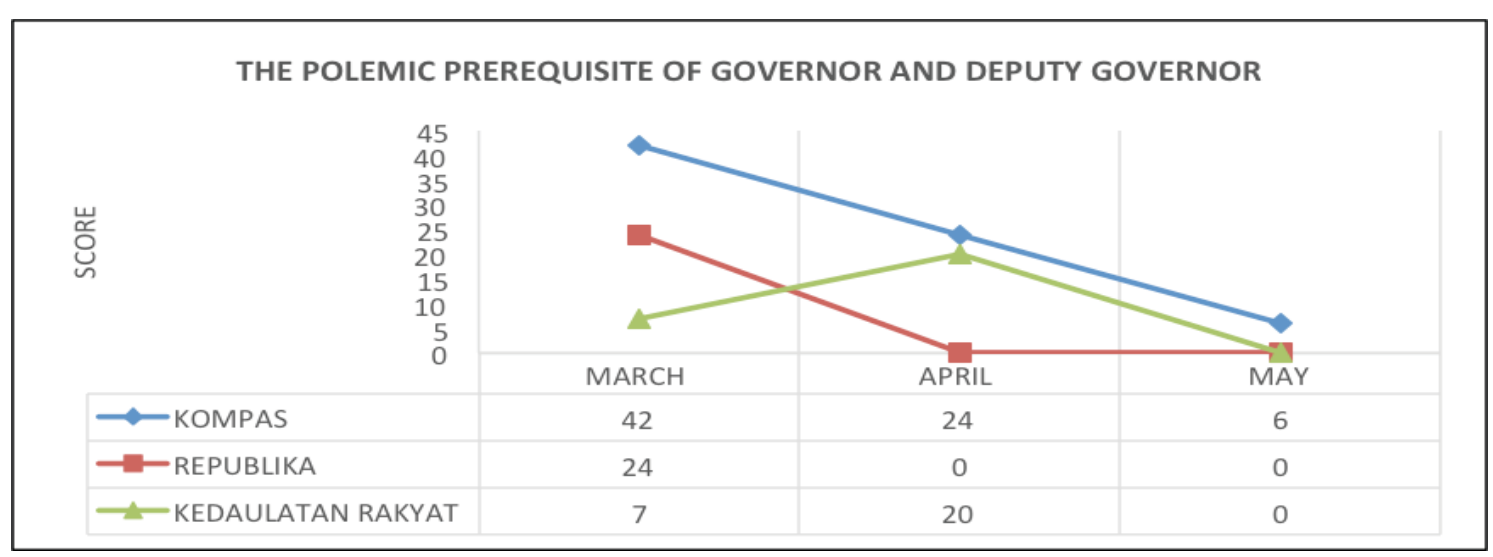

Source: Research result 2019 
Tracking the media agenda by month for the polemic Prerequisite of Governor and Deputy Governor (see table 5). In March 2015 the highest news score dominated by national newspapers. KOMPAS and Republika put their agendas in this issue in March 2015 but significantly decrease on April-May 2015. Republika did not even mention it. It indicates that Republika only concern for this issue after the first Sabdatama (King's Order). After that, in April 2015 local Newspaper Kedaulatan Rakyat put their agenda into the prerequisite of governor and deputy governor of Yogyakarta issue while Sultan immediately changed the title of Sultan Hamengku Buwono to Sultan Hamengku Bawono on 30 April 2015. Thus, on May 5, 2015, the Sultan's first daughter GKR Mangkubumi stated as Crown Princess. Surprisingly, local Newspaper Kedaulatan Rakyat did not issue it even the name of the Crown Princess officially released.

Tabel 6. Controversy over Female Ruler or Sultanah Issue from March-May 2015

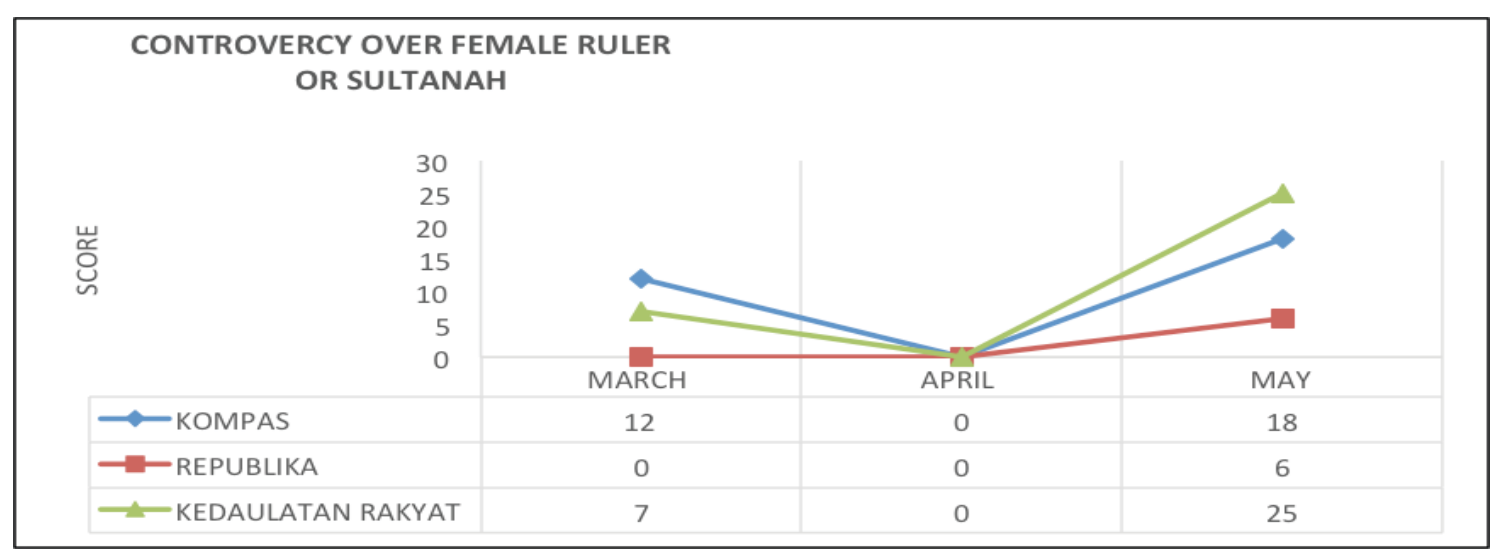

Source: Research result 2019

Tabel 7. Female Governor in Yogyakarta issue from March-May 2015

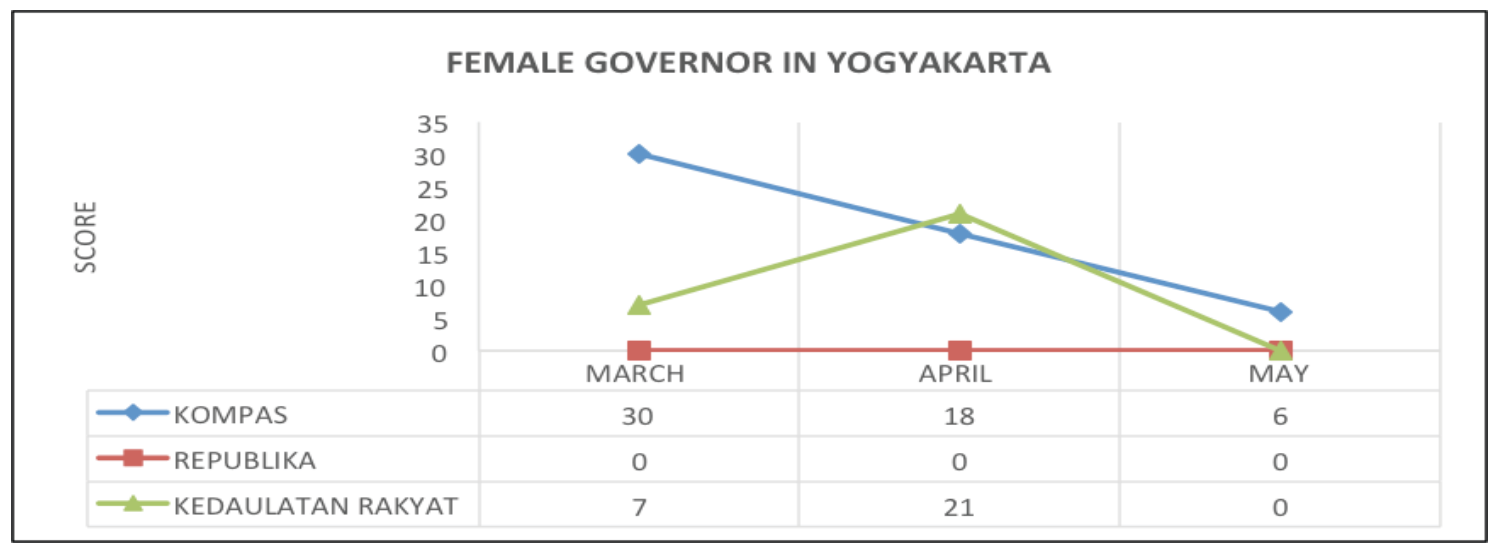

Source: Research result 2019

According to the Sultanate Succession issue in Yogyakarta, the appearance of the Crown Princess brought discussion in a patriarchal society in Yogyakarta because anyone who was the leader of the Yogyakarta sultanate would also hold the governor's political position. For a few centuries, the position of the Sultan was never occupied by women. Hence the existence of a princess crown is a culturally and politically controversial matter. The results of the study gave rise to a media agenda related to women in the issue of Sultanate succession. There were two sub-issues related to women, the first issue is related to the controversy of a female ruler or Sultanah. This has emerged in the public since the establishment of GKR Mangkubumi as the 
crown princess. The second relates to the female governor who automatically attributes to the GKR Mangkubumi when she is ascending the throne to become Sultanah. Discussions about female leaders were raised when the first Sabdatama was issued. After the measurement, two special sub-issues surround the issue of sultanate succession in Yogyakarta. In table 6 and table 7, the data relating to the sub-issue are presented in the context over female ruler or Sultan and female Governor in Yogyakarta.

In table 6, KOMPAS and Kedaulatan Rakyat place their agenda on this issue in March 2015 and May 2015. Whereas Republika attended this issue only in May 2015. KOMPAS put attention on this sub-issue, the total news scoring from March-May 2015 was 30. However, this figure is still far behind the attention of the local newspaper Kedaulatan Rakyat with a score of 32. Republika itself does not give attention to this issue. The issue movement in table 6 , the highest portion of attention in May 2015, this occurred in the three daily newspapers. The controversy regarding Sultanah emerged when Sabdatama was first issued in March 2015 and at the time GKR Mangkubumi has declared a Crown Princess. Crown Princess GKR Mangkubumi is predicted to replace the Sultan and become the first Sultanah in the history of the Kingdom of Yogyakarta.

In the next sub-issue, in table 7, the sub-issues that arise related to the discussion about female Governor. When the Sultan ascended the throne, automatically she occupied the position of governor of the province of Yogyakarta. The emergence of dissent was related to the Special Law of Yogyakarta article 18 paragraph (1) letter $\mathrm{m}$ which implicitly required candidates for governor and vice-governor of the Special Region of Yogyakarta to be male. Among the 3 media, during March-May 2015 COMPASS was the most massive and intense in giving a portion to this issue with a total score of 54. Public sovereignty gave a small portion of attention from March-April 2015, surprisingly Kedaulatan Rakyat did not report anything about the issue of Female Governor, but more emphasis on the issue of Female Ruler in Yogyakarta (refer to table 6). Surprisingly, Republika does not include this issue in its media agenda.

Tabel 8. Democracy issue from March-May 2015

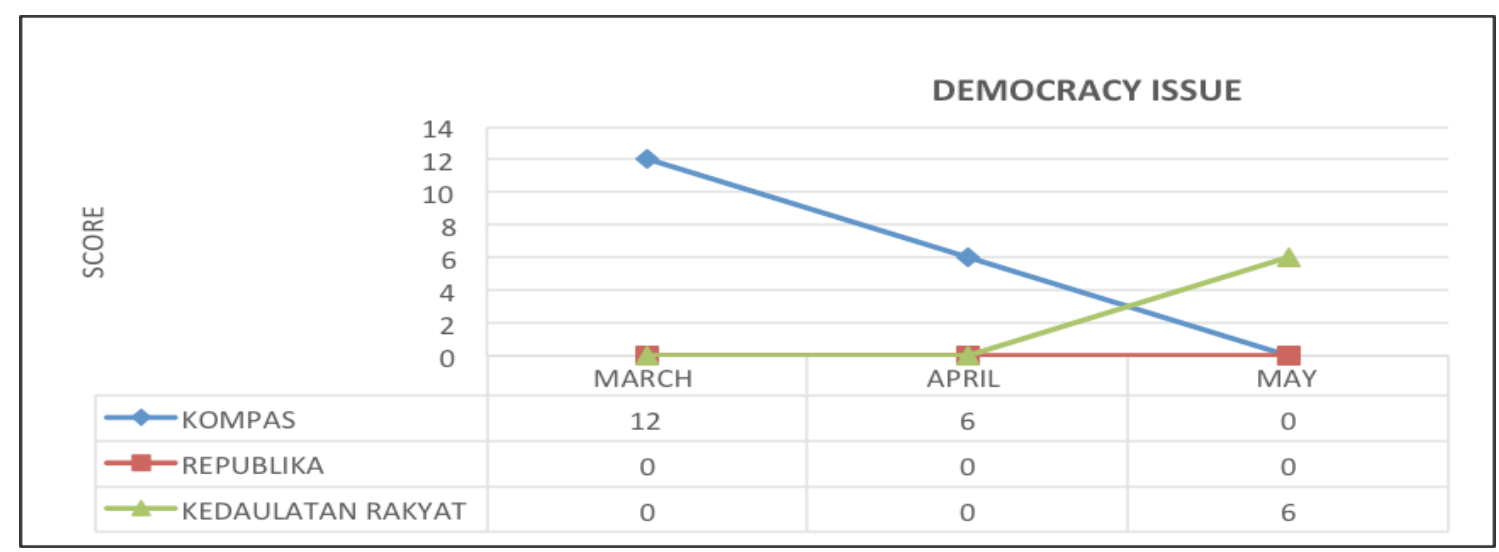

Source: Research result 2019

The power in Yogyakarta is not entirely under the control of the Sultan's hand, but there is still a system of supervision in implementing regional government. The implication of the Yogyakarta Privileges Law is a system of monarchy that goes hand in hand with a democratic system. Democracy becomes a spirit in the asymmetric decentralization that Yogyakarta undertakes. However, comparing data in tables 8 and 9, the issue of monarchy pulled more media attention. Democracy is not widely discussed by the media. Media agenda is a determination issue that is considered important to be reported in the media. Usually, 
the media agenda is poured out in the order of priority. Merheim said that the media agenda consists of issues, actors, events, assumptions, and views that take advantage of time and space in the available publications to be submitted is public (Nasionalita, 2014).

Tabel 9. Monarchy issue from March-May 2015

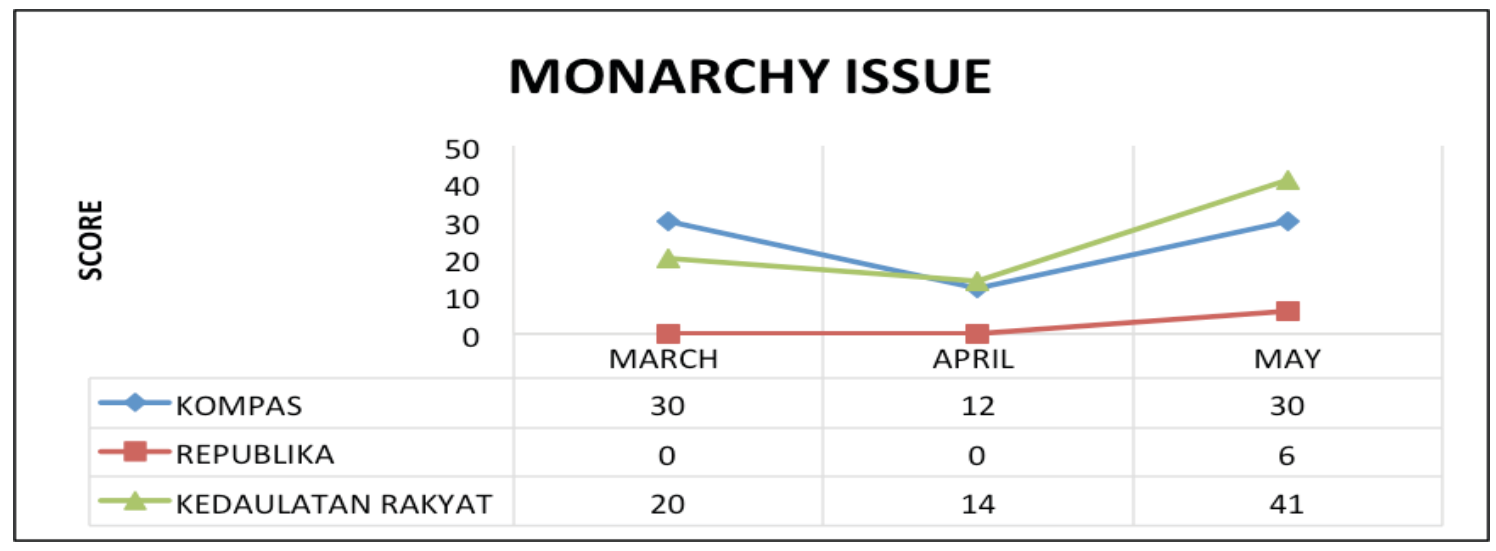

Source: Research result 2019

Tabel 10. Monarchy issue from March-May 2015

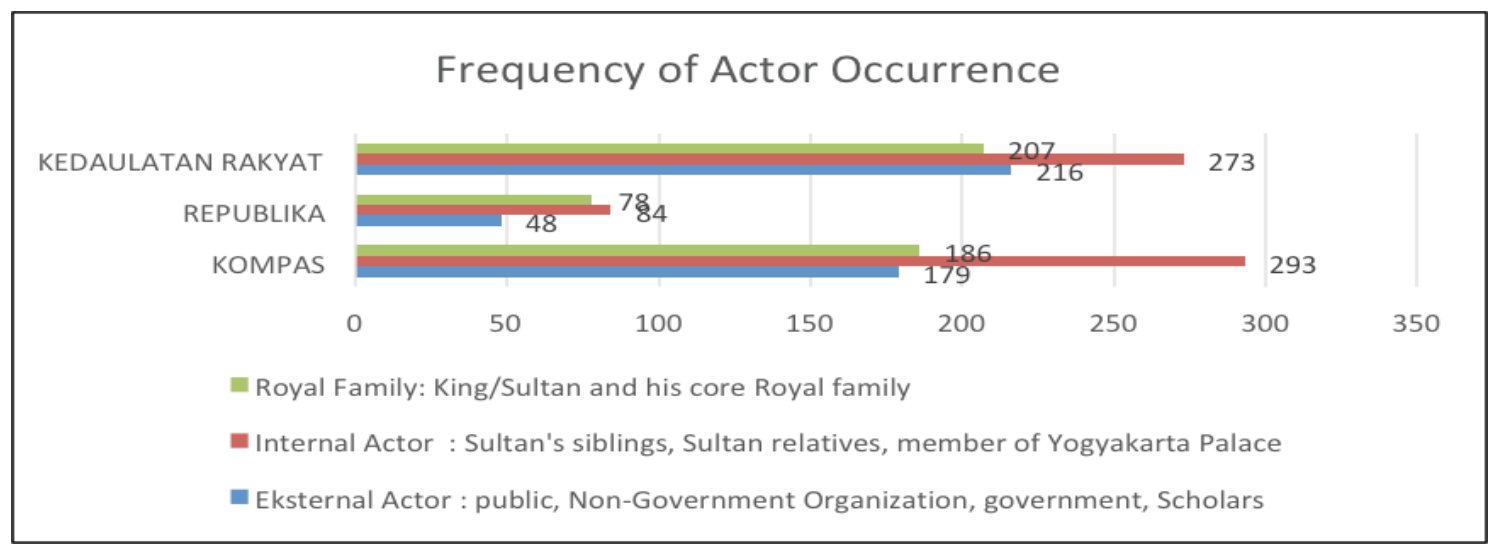

Source: Research result 2019

Some actors are seen as mentioned in news content for each newspaper. The frequency of occurrence of actor groups, in general, is dominated by groups of actors from the internal Sultanate of Yogyakarta outside the royal family while the external actors who appear the least.

According to how the media places attention towards special issues, several studies emphasize on media content. For the mass-media especially gatekeepers sets their efforts to gain attention from the public. They present special treatment for media content in the editorial room. The agenda-setting of the prominence of certain issues by the mass media should not be separated from the media selection process, this selection process has stages or several doors (gates), can individuals or groups decide is newsworthy of loading. These are those who play a role in informing the reality in the public - called the gatekeeper. Usually, the gatekeeper determines the weight of the issue presentation based on how much space provided, the prominence of news (size of headlines and location placement page), and the way the issue is discussed in detail or in general (DeGeorge, 1981). Media Agenda is a determination issue that is considered important to be reported in media. Usually, the media agenda is poured out in the order of priority. Merheim states that the media agenda consists of issues, actors, events, assumptions, and views that take advantage of time and space in the available publications to 
be submitted is public (Nasionalita, 2014).

In its coverage, KOMPAS accommodates more on the interests of nationalist groups because they were historically close to them. Likewise in reporting on the issue of leadership succession in Yogyakarta, KOMPAS tries to appear by accommodating the interests of certain groups fighting in the conflict. As is known that the Sultanate succession in Yogyakarta has dragged various interests and social and political actors not only in the area of local politics but also in the area of national politics. From research findings, KOMPAS strongly bold issues rank: first about Sabdatama (King's Order), then Prerequisite of Governor \& Deputy Governor and female Governor in Yogyakarta.

The next media that became the object of this research was Republika, which also discussed the issue of leadership succession in Yogyakarta because it was related to the dynamics of national politics, especially related to the growing politics with Islamic ideology. Islam puts a strong position for a male to be a leader. Republika underlined their attention into issues rank: Top rank issue is Sabdatama (King's Order), then Prerequisite of Governor \& Deputy Governor. In third place, Republika equally gives attention for controversy of female ruler, democracy, and monarchy issues. Yogyakarta as part of the territory of Indonesia has a strategic role and position in the national political arena.

From the beginning of its establishment, Republika openly called itself an Islamic media, so that the media always saw and assessed issues that developed in the community from an Islamic perspective. As (Hill, 2003) stated that Republika was built when ICMI or Ikatan Cendekiawan Muslim Indonesia identified a common enemy, namely a minority group that controlled the media conglomerate and deliberately covered Islamic activities professionally. Republika is the largest Islamic breathing newspaper with circulation areas in Jabodetabek and Banten (62\%), West Java (13\%), Central Java and DIY (11\%), East Java (5\%), and other regions $9 \%$. When there was a tug-of-war between various interests in the issue of succession in Yogyakarta which was a concern and fight of politicians at the local and national level, Republika was quite intense in reporting on the issue of succession in Yogyakarta. As a media that has an alignment with Islamic ideological groups, Republika is alleged to accommodate interests that are close to Islamic interests. As we know that one of the contents of the Sabda Raja (King's Order) is issued by Sultan HB X is to remove the title "khalifatullah" which means removing the obligation of the Sultan as a leader and protector for Muslims in Yogyakarta.

As the oldest and largest local daily newspaper in Yogyakarta, Kedaulatan Rakyat has an interest in the dynamics of local politics in the Yogyakarta region as its customer base. Kedaulatan Rakyat as one of the oldest newspapers in Indonesia has a fairly strategic role in the context of local politics, so it is feasible to analyze how Kedaulatan Rakyat produces texts related to the issue of leadership succession in Yogyakarta. Next for Kedaulatan Rakyat put three main issues: Sabdatama (King's Order), the Monarchy issue, and controversy over female ruler in Yogyakarta.

\section{CONCLUSION}

The research concludes that KOMPAS media agenda strongly bold issues rank: first regarding Sabdatama (King's Order), then Prerequisite of Governor \& Deputy Governor and female Governor in Yogyakarta. Republika media agenda underlined their attention into issues rank: First, top rank issue is Sabdatama (King's Order), then Prerequisite of Governor \& Deputy Governor. In the third place, Republika equally gives attention for controversy of female ruler, democracy, and monarchy issues. Lastly, Kedaulatan Rakyat put three main issues: Sabdatama (King's Order), the Monarchy issue, and controversy over female ruler in Yogyakarta. This 
DOI: $10.24198 / \mathrm{jkj} . \mathrm{v} 4 \mathrm{i} 1.24071$

research also has found related to the frequency of occurrence of actor groups mentioned in news content in general, is dominated by groups of actors from the internal sultanate of Yogyakarta outside the royal family while the external actors who appear the least. This finding can be a recommendation to carry out further research to dissect the interrelationships between actors through the communication networks analysis.

\section{REFERENCES}

DeGeorge, W. F. (1981). Conceptualization and Measurement of Audience Agenda. California: Sage Publication.

Eriyanto. (2011). Analisis Isi: Pengantar Metodologi untuk Penelitian Ilmu Komunikasi dan Ilmu-ilmu Sosial Lainnya. Jakarta: Kencana.

Griffin, EM, Ledbetter, Andrew, and Sparks, G. (2019). A First Look at Communication Theory (10th ed.). New York: Mc Grew Hills Education.

Hamad, I. (2004). KONSTRUKSI REALITAS POLITIK DALAM MEDIA MASSA (Studi Pesan Politik Dalam Media Cetak Pada Masa Pemilu 1999). Makara Human Behavior Studies in Asia. https://doi.org/10.7454/mssh.v8i1.77

Hill, D. T. (2003). Communication for a new democracy: Indonesia's first online elections. Pacific Review. https://doi.org/10.1080/0951274032000132245

Lang, Gladys E dan Lang, K. (1981). Watergate: An Exploration of Agenda Setting. Beverly Hills, CA/London: Sage Publicaton.

Lesmana, T. (2017). Journalist as Professional versus Employee - a Case of Daily Koran Sindo in Censoring News on Trump's Travel-Ban Policy. Komunikasi ISKI, II(2), 109-119. https://doi.org/http://dx.doi.org/10.25008/jkiski.v2i2.106

McCombs, M., \& Shaw, D. (2016). The Agenda-Setting function of mass media. In Agenda Setting: Readings on Media, Public Opinion, and Policymaking. https://doi. org/10.4324/9781315538389

Mrogers, E., \& Wdearing, J. (1988). Agenda-Setting Research: Where Has It Been, Where Is It Going? Annals of the International Communication Association. https://doi.org/10.10 80/23808985.1988.11678708

Nasionalita, K. (2014). RELEVANSI TEORI AGENDA SETTING DALAM DUNIA TANPA BATAS. Jurnal Ilmiah Komunikasi Makna. https://doi.org/10.30659/jikm.5.2.156-164

Nugroho, C. (2014). Konstruksi Berita Kontroversi Rancangan Undang-Undang Keistimewaan Yogyakarta (Analisis Framing Pan dan Kosicki Terhadap Berita Surat Kabar Harian Kompas dan Kedaulatan Rakyat Edisi Januari 2011 - Maret 2011). Jurnal Komunikasi, 2(3), 27-43.

Priyonggo, A. (2012). Media and Politics: Examination on the Political Stance of Kompas in Gus Dur's Impeachment Process. Jurnal ULTIMA Comm, 4(2), 60-70. https://doi. org/10.31937/ultimacomm.v4i2.211 